\title{
Discussion on the Theoretical Guidance and Practical Exploration of the Integrated Development of Aesthetic Education and Moral Education in Colleges and Universities
}

\author{
Yu Zhou* \\ Shanghai Institute of Technology, Shanghai, 201418, China
}

\author{
ARTICLE INFO \\ Article history \\ Received: 21 July 2020 \\ Revised: 28 July 2020 \\ Accepted: 9 October 2020 \\ Keywords: \\ Aesthetic education \\ Moral education \\ Integrated development \\ Theoretical guidance \\ Practical exploration
}

Published Online: 16 October 2020

\begin{abstract}
Innovative integration is the development trend of education reform in recent years. Teachers can try to promote the high integration of aesthetic education and moral education from the establishment of music studios, and form a "three-in-one" education and education integration mechanism of classroom teaching, extracurricular activities, and campus culture construction, so as to inherit and innovate the outstanding Chinese traditional music culture and red music culture, and explore the necessity and feasibility of the complementary and integrated development between aesthetic education and moral education.Under the background that the country attaches great importance to inheriting and developing the excellent Chinese traditional culture, taking the integration of music education into college students' moral education as the starting point, exploring the effective ways of vocal music, instrumental music, opera, Chinese folk art, dance, rap and other artistic works to cultivate national builders and successors who have comprehensive development of moral, intellectual, physical, aesthetic, and labor will be definitely to improve the humanistic quality of university and college students, which promotes the Chinese excellent traditional music culture and red music culture, trains college music talents, etc., and promotes the integration and development of large, medium and small aesthetic education and moral education.
\end{abstract}

*Corresponding Author:

Yu Zhou,

female, a native of Yongzhou in Hunan Province, Ph.D. in history from Nanjing University, postdoctoral in public administration at Fudan University, professor at Shanghai Institute of Technology;

Research direction: Chinese modern and contemporary history of thought, ideological and political education, and art education; Correspondence address: Shanghai Institute of Technology, 4th Floor, Sixth Discipline Building, No. 100 Haiquan Road, Fengxian District, Shanghai, 201418, China;

E-mail:fudzhy@163.com.

Fund Project:

The phased achievements of: the 2019 Shanghai School Art Research Project__ "Study on the Collaborative Education of Music Education and Ideological and Political Education" (Project No.: HJYS-2019-A02); the 2018 Ministry of Education Demonstrate Marxist College and the Excellent Teaching and Research Team Construction Project__ "Study of the Early Marxists' Understanding and Application of Chinese Excellent Traditional Culture (Project No.: 18JDSZK075); and the 2019 General Task of Shanghai's Philosophical and Social Planning__ "Study on the Origin of Red Culture in Shanghai" (Project No.: 2019BDS008). 


\section{Introduction}

$\mathrm{F}$ or the cultural mission of a country and a nation, "aesthetic education is perhaps the most powerful in raising emotions to a deep cultural realm." ${ }^{\text {[1] }}$ The "Opinions on Comprehensively Strengthening and Improving Aesthetic Education in Schools and Colleges" issued by the General Office of the State Council states that "Aesthetic education is aesthetic education, sentiment education and spiritual education, which can not only enhance people's aesthetic quality, but also affect people's emotions and interests in a subtle way, however, music is aesthetic, emotional, and serves the public, and is undoubtedly an effective carrier of school moral education, Because "music can express ideas, such as patriotism, nationalism, many positive spirits and beautiful ethics, etc., that is to say, musicians should develop their own creations in ideological activities. ${ }^{,[2]}$ As an educator, we should actively explore the ideological connotation of music, assist moral education with aesthetic education, promote aesthetic education with moral education, and form a positive interaction situation, thereby promoting the integration and innovation of aesthetic education and moral education, and promote the coordinated development of all staff, all-round education.

\section{Innovate the Mechanism of Cultivating Newcomers of the Era of All-Round Development of Moral, Intellectual, Aesthetic, and Labor}

\subsection{Policy Orientation}

University and college aesthetic education is of great significance in comprehensively implementing the fundamental task of educating all employees, "improving students' aesthetic and humanistic qualities, and cultivating socialist builders and successors who have developed morally, intellectually, physically, aesthetically, and laboriously., ${ }^{[3]}$ On July 29, 2010, the "Outline of the National Medium and Long-term Education Reform and Development Plan (2010-2020)" pointed out that it is necessary to strengthen aesthetic education and cultivate students' good aesthetic taste and humanities.In order to implement the education requirements of the country, the party group of the Ministry of Education of the People's Republic of China issued the "Notice on Learning and Implementing the Important Reply Spirit of General Secretary Xi Jinping to the Old Professor of the Central Academy of Fine Arts" on August 31, 2018.The "Notice" emphasized the irreplaceable role of aesthetic education in cultivating all-round develop- ment talents of moral, intellectual, physical, aesthetic and labor."On August 30, 2018,General Secretary Xi Jinping wrote to eight old professors including Zhou Lingzhao of the Central Academy of Fine Arts, and fully affirmed their long-term commitment to the successor training of the motherland, and put forward high expectations for the work of aesthetic education and the promotion of the spirit of China and China.The Ministry of Education requires the majority of educators to study carefully and fully implement the spirit of the important reply from General Secretary Jinping's internship.It is of great significance to promote the reform and development of education in the new era, to implement the fundamental tasks of appointing people, strengthen and improve the work of aesthetic education in schools, and to cultivate socialist builders and successors who have comprehensive development of moral, intellectual and physical beauty." ${ }^{[4]}$ It can be seen that contemporary college students should not only have good professional knowledge and professional skills, but also have high moral consciousness, psychological quality, and aesthetic ability.Because aesthetic education is an important part of "integrity education", that is, "aesthetic education, physical education, and moral education, which pays attention to students' perceptual and rational factors at the same time to achieve coordinated and fully developed education." ${ }^{[5]}$

At the National Education Conference in 2018, Xi Jinping urged educators to "work hard on firm ideals and convictions", and to "work hard to cultivate patriotism." "We must work hard to strengthen moral cultivation." "We work hard to increase knowledge and knowledge."“We work hard to cultivate the spirit of struggle."'We work hard to enhance comprehensive quality." Xi Jinping believes that the newcomers of the times must shoulder the responsibility of national revival and inject new content into the party's education policy.Therefore, if teachers are to cultivate newcomers of the era of comprehensive development of moral, intellectual, physical, artistic, and labor, they must effectively integrate the educational resources of families, schools, and society, and cooperate with the whole society to promote the formation of a new educational situation of integration and development.

Xi Jinping's"3.18" speech pointed out the direction of the construction of ideological and political theory courses in the new period.He emphasized: "Accelerate the modernization of education, build a strong country for education, run a satisfactory education for the people, strive to train newcomers of the era who are responsible for the national rejuvenation, and cultivate socialist builders and successors 
who have comprehensive development of moral, intellectual, artistic, and labor. ${ }^{[7]}$ Among them, the function of aesthetic education to beautify people, cultivate their aesthetic qualities, and promote their all-round development is irreplaceable.Therefore, to deepen the reform of moral education in colleges, optimize the structure of general education in schools, and enrich the ideological and political content of the curriculum, we must integrate the talents of school music and promote the integration of aesthetic and moral education, through system construction and specific path innovation, the sustainable development of aesthetic education and moral education is realized.

\subsection{Guide Students to Lifelong Learning and Diversification}

Practice has proved that the main body of music talent training is professional colleges, but it is also showing a trend of diversified development. The integrated development of aesthetic education and moral education can consolidate the positive results of music teaching in primary and secondary schools, tap music talents, and provide a platform for colleges to choose a major in order to achieve the sustainable development of art education.

Facts have proven that the famous singers Li Guangxi, Yang Hongji, and Liu Huan from non-music professional colleges have made remarkable achievements. "Yang Hongji sings a wide variety of songs and operas. It has been popular so far and has spread widely and has a profound social impact. ${ }^{[8]}$ In recent years, TV stations at all levels have actively explored music drafts.For example, CCTV's "Avenue of Stars" program adheres to the "People's Stage" as its purpose, without thresholds and distances, highlights public participation and entertainment, and strives to provide people in different industries across the country with their talents and dreams. The 2005 championship champion Abao promoted the development of native songs.Phoenix Legend, Alpha, Sam-co, Zayo, Erguna Band, Rangba Na, HaoGe, Li Yugang, Wind \&Cloud Group, Wang Erni, Straw Hat Girl, Hawthorn Girl, Lu Haitao, Wang Erni, Zhu Zhiwen, XuRi Yang Gang, Liu Dacheng, etc. The contestants were recognized by the audience and supported by experts.In early 2015 , the late musician Yan Su wrote an encouragement to the tenth anniversary of The Avenue of Stars.He wrote: "There are singing and laughing here, there are tears and hugs, there is sincerity and no fakes, and there are grass roots and no local tyrants. The bright moon and breeze accompany me running, ten years of frost and snow let me howl, shoulder to shoulder to create together, this is my Avenue of Stars! ${ }^{,[9]}$ Ping An and JikeJunyi made their debut with the help of Zhejiang Satellite TV's "The Voice of China" draft;HuoZun appeared with the help of Oriental TV's reality show "AsianWave";Zhu Zhiwen, a peasant singer, has become famous with the help of the show "I Amthe Big Star" in Jining, Shandong.Professor Jin Tielin believes that Zhu Zhiwen"has a good voice and is suitable for singing songs of fellow countrymen. Not only can he sing many songs, but also his own characteristics. This is the key." ${ }^{[10]}$ These are the facts that the cultivation of music talents is not unique to professional music colleges.

\subsection{Set up Music Studio Innovative Teaching Mechanism}

Confucius, the founder of Confucianism (551 BC-479 $\mathrm{BC})$, combined artistic activities with the cultivation of people who meet his social ideals from the perspective of music education practice, emphasizing:"Rise in poetry, stand in courtesy, and succeed in music." Starting from the ideological and artistic quality of music, he takes "goodness" and "beauty" as the basic criteria for music evaluation, and derives the "perfect and perfect" aesthetic evaluation standard.Confucius also attaches great importance to music education, and proposes six lessons for study, "ceremony, music, archery, horse-drawn carriage, reading, and math". Among them, "music" is the second. It is the stage of formation of the "Three Views."

Once the performance or singing of a musical work reaches a high degree of consistency in artistic technique and content expression, it will inevitably achieve the purpose of subtleness, education and education, making"the upright and the brave listen to it, then the strength will increase; the filial piety performers listen to it, they will be emotionally hurt; the poor and the lonely listen to it, they will run away; and the rumbling people will listen to it, they will converge solemnly." "[1]

Music works contain rich moral education resources, and the knowledge of Chinese learning, the history of revolution, patriotism, and socialism should be strengthened through education and teaching activities, to ensure the smooth progress of education and teaching, it is necessary for colleges and universities to set up special music studios to promote the coexistence, collaborative innovation, and integrated development of music education and moral education, so as to form reproducible and expandable experiences, optimize the structure of general education in schools, integrate the team of moral education teachers and counselors, and explore the integration of music elements into classroom teaching, community activities, and village activities, whichensures the unity of daily work and music teaching practice. 


\section{Explore the Path of Integrated Development of Daily Teaching, Second Classroom, and Campus Culture}

In the process of teaching, teachers should pay attention to both cover works and original works. It is the teaching work to maintain innovative vitality.Jin Tielin believes: "If the singer is limited by his personal singing level and artistic accomplishment, he cannot express the emotional experience of the songwriters in his works, and the audience cannot get emotional resonance and beauty feelings, or get inspiration and lessons from it, well, it's hard to say what kind of contagious such a singing is, his singing lacks 'artistic'., ${ }^{[12]}$

\subsection{Routine Teaching}

Because "the moral education textbooks of universities are theorized, they lose their appeal because of empty lectures. Nowadays, politics courses in colleges are compulsory and they account for a large proportion of the credits of college students. ${ }^{,[13]}$ Therefore, the music works correspond to the corresponding chapters of moral education such as "Introduction to the Basic Principles of Marxism", "Introduction to the Theoretical System of Mao Zedong and Socialism with Chinese Characteristics", "Outline of Modern and Contemporary History of China", "Legal Foundation and Ideological and Moral Cultivation", organizing case teaching can improve teaching effectiveness. For example, in order to incorporate the ideas of the "Belt and Road" and "Community of Human Destiny" into the relevant content of moral education textbooks, you can incorporate the song of the original work "Great Harmony of the World" into the relevant content of textbooks. (See Table 1 and the song sheet of "Great Harmony of the World")

\section{Table 1}

\begin{tabular}{|c|c|c|c|}
\hline Textbook Name & Chapter /Section / Part & Content Description & Page \\
\hline $\begin{array}{l}\text { Introduction } \\
\text { to the Basic } \\
\text { Principles of } \\
\text { Marxism }\end{array}$ & $\begin{array}{c}\text { Chapter } 5 . \\
\text { Development and Trend } \\
\text { of Capitalism } \\
\text { Section 1. Development } \\
\text { of Monopoly } \\
\text { Capitalism } \\
\text { Part } 3 \text {. Impact } \\
\text { of Economic } \\
\text { Globalization }\end{array}$ & $\begin{array}{l}\text { Facing the differences } \\
\text { in production methods, } \\
\text { development levels, and } \\
\text { cultural backgrounds } \\
\text { of different countries, it } \\
\text { is necessary to lead the } \\
\text { economic globalization } \\
\text { with the concept of } \\
\text { building a community } \\
\text { of shared future for } \\
\text { humanity. }\end{array}$ & 232- \\
\hline
\end{tabular}

\begin{tabular}{|c|c|c|c|}
\hline \multirow[t]{2}{*}{$\begin{array}{c}\text { Ideological } \\
\text { and Moral } \\
\text { Cultivation and } \\
\text { Legal Basis }\end{array}$} & $\begin{array}{c}\text { Chapter 3. Carrying } \\
\text { Forward the Chinese } \\
\text { Spirit } \\
\text { Section 2. Patriotism } \\
\text { and the Requirements } \\
\text { of Its Time } \\
\text { Part 2. Patriotism in the } \\
\text { New Era }\end{array}$ & $\begin{array}{c}\text { Adhering to the } \\
\text { construction of a } \\
\text { community with a } \\
\text { shared future for } \\
\text { mankind is an important } \\
\text { part of the basic } \\
\text { strategy of adhering } \\
\text { to and developing } \\
\text { socialism with Chinese } \\
\text { characteristics in the } \\
\text { new era. }\end{array}$ & 60 \\
\hline & $\begin{array}{c}\text { Part 3. Be a Loyal } \\
\text { Patriot }\end{array}$ & $\begin{array}{c}\text { Create a community } \\
\text { of shared future for } \\
\text { mankind and push the } \\
\text { world towards the goal } \\
\text { of mutual benefit and } \\
\text { common security. }\end{array}$ & 65 \\
\hline $\begin{array}{c}\text { Outline of } \\
\text { Chinese } \\
\text { Modern History }\end{array}$ & $\begin{array}{l}\text { Section } 2 \text { The Historic } \\
\text { Achievements and } \\
\text { Historic Changes of the } \\
\text { Party and the State } \\
\text { Part 1. An Extraordinary } \\
\text { Five Years }\end{array}$ & $\begin{array}{l}\text { Advocate the building } \\
\text { of a community of } \\
\text { shared future for } \\
\text { mankind and promote } \\
\text { changes in the global } \\
\text { governance system. }\end{array}$ & 240 \\
\hline \multirow{5}{*}{$\begin{array}{c}\text { An Introduction } \\
\text { to Mao Zedong } \\
\text { Thought and } \\
\text { the Theoretical } \\
\text { System of } \\
\text { Socialism } \\
\text { with Chinese } \\
\text { Characteristics }\end{array}$} & $\begin{array}{c}\text { Chapter 8. Xi } \\
\text { Jinping's Thoughts on } \\
\text { Socialism with Chinese } \\
\text { Characteristics and Its } \\
\text { Historical Status in the } \\
\text { New Era } \\
\text { Section 1. Socialism } \\
\text { with Chinese } \\
\text { Characteristics Enters a } \\
\text { New Era } \\
\text { Part 2. Changes } \\
\text { in major social } \\
\text { contradictions }\end{array}$ & $\begin{array}{l}\text { Implement the "One } \\
\text { Belt, One Road" } \\
\text { initiative, advocate } \\
\text { the construction } \\
\text { of a community of } \\
\text { shared future for } \\
\text { mankind, promote the } \\
\text { transformation of the } \\
\text { global governance } \\
\text { system, and make } \\
\text { new and significant } \\
\text { contributions to world } \\
\text { peace and development. }\end{array}$ & 177 \\
\hline & \multirow{2}{*}{$\begin{array}{c}\text { Section 2. Main } \\
\text { Contents of Xi } \\
\text { Jinping's Thoughts on } \\
\text { Socialism with Chinese } \\
\text { Characteristics in the } \\
\text { New Era } \\
\text { Part 2. Adhere to } \\
\text { and Develop the } \\
\text { Basic Strategy of } \\
\text { Socialism with Chinese } \\
\text { Characteristics }\end{array}$} & $\begin{array}{l}\text { The diplomacy of the } \\
\text { great powers with } \\
\text { Chinese characteristics } \\
\text { should promote the } \\
\text { construction of a new } \\
\text { type of international } \\
\text { relations and the } \\
\text { construction of a } \\
\text { community of shared } \\
\text { future for mankind. }\end{array}$ & 184 \\
\hline & & $\begin{array}{l}\text { Persist in advancing } \\
\text { the building of a } \\
\text { community of shared } \\
\text { future for humanity. }\end{array}$ & 188 \\
\hline & $\begin{array}{c}\text { Section 3. Historical } \\
\text { Position of Xi Jinping's } \\
\text { Socialist Thought with } \\
\text { Chinese Characteristics } \\
\text { in the New Era } \\
\text { Part } 1 . \text { The Latest } \\
\text { Achievements of } \\
\text { Sinicization of Marxism }\end{array}$ & $\begin{array}{l}\text { Xi Jinping answered } \\
\text { a major question } \\
\text { concerning the future } \\
\text { and destiny of mankind, } \\
\text { the community of } \\
\text { human destiny. }\end{array}$ & 190 \\
\hline & $\begin{array}{l}\text { Chapter 13. Diplomacy } \\
\text { of Great Powers with } \\
\text { Chinese Characteristics } \\
\text { Section 2. Promoting } \\
\text { the Construction of a } \\
\text { Community of Human } \\
\text { Destiny }\end{array}$ & $\begin{array}{l}\text { The Connotation of } \\
\text { the Idea of Building a } \\
\text { Community of Human } \\
\text { Destiny }\end{array}$ & $\begin{array}{l}289- \\
297\end{array}$ \\
\hline
\end{tabular}




\begin{tabular}{|c|c|}
\hline Situation and & $\begin{array}{c}\text { The "loose-leaffor the teaching of ideological and } \\
\text { political theories in colleges and universities" } \\
\text { promptly pushed forward a series of content about the } \\
\text { PCO Qingdao Summit, such as: carrying forward the } \\
\text { "Shanghai Spirit" to break through the difficulties of } \\
\text { the times, "Shanghai Spirit" promotes the practice of } \\
\text { new-type international relations, etc., and objectively } \\
\text { guided and helped teachers to carry out special } \\
\text { teaching on the "Shanghai Spirit". }\end{array}$ \\
\hline
\end{tabular}

$$
\text { 天下大同 }
$$

$1=\mathrm{C} \frac{4}{4}$

Great Harmony of the World

Lyricist: Wu Jiangong Composer: Chang Yunlang cnzhipu.com

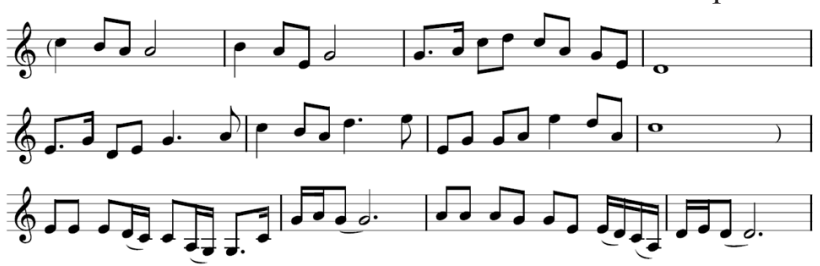

Yesterday there was a joyful encounter at green Rhine, Today we enjoy the fragrant red of peony together.

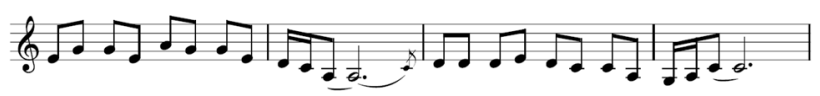

Yesterday there was a joyful encounter at green Rhine, Today we enjoy the fragrant red of peony together.

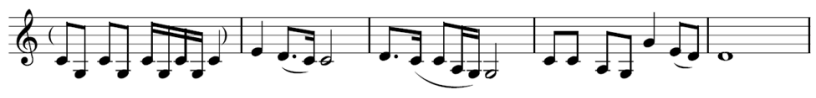

The wind wave is flat, The rainbow is set,Phoenix resting on a sycamore tree

The God of Liberty, The Elder Angler, Keep watching friendly, mind-to-heart

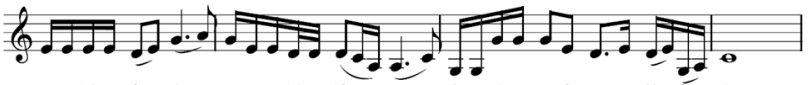

Different nocturnes sing the same feelings, East and west wanderers share bright moon at silent night

Different languages express the same desire, Everybody bathe together in spring scenery with warmth

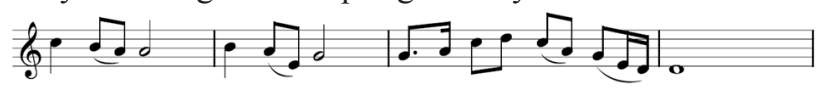

Look over the boundless, Resound through the sky, The world loves to sing Great Harmony

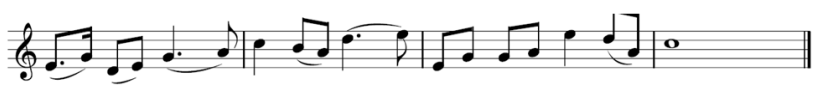

Look over the boundless, Resound through the sky, The world loves to sing Great Harmony

\subsection{Social Practice Teaching}

According to the 2019 teaching plan, there are 6 in-class practical lessons in the teaching plan of each course. Teachers can respond to social practice teaching activities and design social practice topics related to music and art. Divide students into groups of 4-8, and select vocal music, instrumental music, film and television, opera and other related music topics for discussion. The practice report can be divided into links such as material selection analysis, creative background, works appreciation, inquiry learning, and performance practice.The selection of materials can be cover, imitation, originality, encourage originality, and train talents.At that time, MeiliQige wrote "The Rising Sun on the Prairie", which was his work at the Central Conservatory of Music, and later became a teaching song and a famous song.

\subsection{Music Education Integrated into the Second Classroom}

Each school has student art groups of varying sizes, some belonging to the Youth League Committee, some to the Student Office or the Ministry of Education and Industry. These two departments are organizations that organize large-scale events in various schools, and gather most of the music professional counselors and have a good working foundation.Due to the limited time available for art education in non-art schools, "and student clubs such as choirs and dance teams have a variety of activities to meet the needs of different students. Even for operas, Musical instruments and other forms of music that are unsuitable for introduction in the classroom can also play a positive and complementary role in the activities of student associations. " ${ }^{[14]}$ The first is to use social practice, theoretical lectures, academic activities and other platforms to rehearse vocal music, instrumental music, dance, opera, rap, speech and other programs at a fixed time.The second is to perform and interact in student communities, villages (residences), and communities. The third is to set up "Artist Interpretation of Classics" lectures, and regularly invite well-known artists in the arts and culture to cultivate students' correct cognition vividly with their own understanding of the national classics and their growth and success. The fourth is the use of major festivals (such as May Fourth Youth Day, July 1st Party, 11 National Day, 129 Movement, etc.) to carry out singing activities, and constantly consolidate the effect of the integration of moral and aesthetic education. 


\section{Focus on Red Music Teaching to Promote the Integration of Aesthetic Education and Moral Education in Primary and Secondary Schools}

Red music is an effective carrier of Chinese traditional culture and red genes. The broad sense of red music belongs to the category of music that not only reflects the excellent traditional cultural genes of the Chinese nation, but also accepts and integrates the world's outstanding cultural achievements.Its basic characteristics are: it is the music born in the 5000-year long historical environment of the Chinese nation, growing with our nation, and melting in the blood of people's life; it is a piece of music that reflects the arduous struggle of the Chinese people under the leadership of the Communist Party of China, from standing up, getting rich to becoming strong; it is music that is healthy and uplifting, enlightens the mind, purifies the soul, and reflects the people's growing needs for a better life.

Narrow red music refers to: "For nearly a century, this red music that has been accumulated and continued to develop has become the most precious spiritual wealth of the Chinese nation, and has become a red classic that carries and represents the transformation and development of Chinese society." ${ }^{[15]}$ As an important part of the history of Chinese new music culture development in modern China, the red music developed from the Great Revolution period contains the humanistic spirit of the Chinese nation and the thoughts and emotions of the Chinese people. It sings every wonderful moment and moving story from the revolutionary war to the period of socialist construction. It can be said that for a long time red music has played an important role in emancipating the mind, popularizing Marxism, and spreading the policy of the Communist Party of China. It has also left many classic works.

It is particularly concerned that early Marxists had a fine tradition of focusing on the use of music to spread Marxism and promote the Sinicization, epochization and popularization of Marxism.QuQiubai is a typical representative of the Communists who first paid attention to music issues and engaged in the distribution and creation of red music. QuQiubai translated "International Song" and composed "Red Tide Song", which had a great impact.JuQihong believes: "He not only has a "record of music on the string', he can already see his love for music and art, and is the first translator to publish the complete Chinese version of the International Song. The song "Red Tide" written and composed by him is the earliest original revolutionary song in China and has important historical and cultural value in the history of Chinese red music. "“[16]
In terms of red music teaching resources, the songs selected in "Songs forNinety Years", "Building the Chinese Dream Together:" Chinese Dream "Theme New Songs Concert", "Our Forty Years_- the 40th Anniversary Literary Party to Celebrate Reform and Opening up" and the programs in Large-scale music and dance epic "Fight now!" The Chinese Children "show, have all clearly reflected the history of the Chinese Communist Party that gave the Chinese people a backbone, and the historical achievements of social construction and reform and opening up. It is an effective reference for teachers to explore red music culture in the classroom.

In terms of the teaching goals of red music, we can take Xi Jinping's spirit that "the Republic is red and we cannot dilute this color" ${ }^{\text {"[17] }}$.Xi Jinping particularly hopes that elementary school students will set up great ambitions from an early age, and to be useful to the country, the people, and the society, they must use practical actions to pass on the red gene from generation to generation.In his letter of June 1, 2018, to the students of ShaojiangZhaojinBeiliangRed Army Primary School, he requested:"You said in your letter that the old people in the village often tell you the history of the revolution according to Jin. This red land makes you proud and proud.I hope you will learn more about the historical knowledge of the Chinese revolution, construction, and reform, learn more from samples and heroes love the party, the motherland, and the people, and pass on the red gene from generation to generation with practical actions. ${ }^{,[18]}$ This important reply is the fundamental observance of the integrated practice of music education and moral education in primary and secondary schools.

\section{Conclusion}

Aesthetic education and moral education serve the same purpose. They substantially improve the fair, just, and harmonious social life of each educated, and improves the quality of life of healthy and happy individuals.This means that the multi-disciplinary integration and development is a practical need to train newcomers with the comprehensive development of moral, intellectual, physical, aesthetic, and labor.Xi Jinping emphasized: "To make good use of the main channel of classroom teaching, ideological and political theory lessons must be strengthened in improvement to improve the affinity and pertinence of ideological and political education, so as to meet the needs of students' growth and development and to look forward to other courses, we must keep a good canal and plant fields of responsibility so that various courses and ideological and political theory courses go in the same direction and form a synergistic effect."Colleges 
and universities in the new era should pay attention to the coordinated development of moral education and aesthetic education in order to "have important value connotation to better shape the perfect personality of individual students, enhance the effectiveness of moral education in universities, improve the quality of talent training, and cultivate socialist builders and successors." ${ }^{,[20]}$ Colleges and universities should be committed to innovative ideas, innovative carriers, innovative management, and innovative environments, and strive to create a long-term mechanism for the integrated development of moral and aesthetic education.

\section{References}

[1] Yang Heping and Wu Yuanhua: "Responsibility for Aesthetic Education in the New Era", China Social Science News, October 28, 2019. (in Chinese)

[2] Zhao Jiping: "Preface 1", see LuoYifeng's"Five Lectures on the History of Chinese Music Thought", Shanghai Music Press 2013, p. 3.(in Chinese)

[3] Huanghuang Sun: "Strengthening the Construction of Aesthetic Education Faculty in Colleges and Universities in the New Era", China Social Science News, October 28, 2019. [4] Education Party [2018] No. 48.(in Chinese)

[5] Jiang Nan: "The role of aesthetic education in the comprehensive development of contemporary college students", "Contemporary Music", No. 18, 2016, p. 30.(in Chinese)

[6] "Xi Jinping emphasized at the National Education Conference: Adhere to the development path of socialist education with Chinese characteristics, cultivate socialist builders and successors of the comprehensive development of moral, intellectual, physical, artistic, and labor", People's Daily, September 11, 2018, No. 1 Version.(in Chinese)

[7] "Efforts to Cultivate New Era in the Role of National Revival-Delegates from School Ideological and Political Theory Teachers' Forum Debating Important Speech by General Secretary Xi Jinping", People's Daily, March 19, 2019, 4th edition.(in Chinese)

[8] GuoJianmin and GuoYiyang: "Theoretical Interpretation of Singer Yang Hongji's Opera Performance Art", Contemporary Music, Issue 3, 2018.(in Chinese)

[9] Zhu Xun: "Touching the Spiritual Texture of Every- one with True Feelings-An Abstract of the Report of the Advanced Deeds by the Empty Text Workers' Group, Yan Su,"“The People's Liberation Army Daily • Military Culture," 7th Edition, December 26, 2015, 1st page.(in Chinese)

[10] Nongyan Village: "For the evaluation of peasant singer Zhu Zhiwen, the director of China Conservatory of Music Jin Tielin gave it very objectively! ", Sina.com, February 02, 2018.(in Chinese)

[11] XuYuanyong: "Review of the Research on the History of Ancient Chinese Music", Anhui Literature and Art Publishing House, 2012 edition, p. 76.(in Chinese)

[12] Jin Tielin: "Jin Tielin's Vocal Music Teaching Art", People's Music Publishing House, 2008, p.26.(in Chinese)

[13] Huang Yubin: "Research on Innovating Moral Education in Colleges and Universities from the Perspective of Aesthetic Education", "Education and Occupation", 2014 No. 20, p. 49.(in Chinese)

[14] Li Jia, "On Student Association Activities in Higher Vocational Music Education", "Education and Occupation", 2006, No. 8, p. 103.(in Chinese)

[15] Liu Hui: An Introduction to Red Classical Music, Southwest Normal University Press, 2015, p. 1.(in Chinese)

[16] JuQihong: QuQiubai and Early Chinese Red Music, Music Exploration, No. 4, 2016, p. 20.(in Chinese)

[17] The first edition of People's Daily, June 1, 2018.(in Chinese)

[18] People's Network Hebei Channel, March 13, 2019.(in Chinese)

[19] "Xi Jinping's Speech at the National Conference on Ideological and Political Work" (December 7-8, 2016), People's Daily, December 9, 2016, first edition.(in Chinese)

[20] Li Jiaxin and Lou Shuhua: "Value Connotation and Practice Path of the Coordinated Development of Moral and Aesthetic Education in Colleges and Universities in the New Era", "Ideological and Theoretical Education Guide", Issue 5, 2019, p.138. (in Chinese) 